\title{
Actions of nurses in early detection of breast cancer
}

\author{
Ações do enfermeiro na deteç̧ão precoce do câncer de mama \\ Las prácticas de enfermeros en la detección precoz del cáncer de mama
}

\section{Fabiana Barbosa Barreto Melo', Carla Andréia Vilanova Marques', Anderson da Silva Rosa', Elisabeth Niglio de Figueiredo', Maria Gaby Rivero de Gutiérrez'}

' Universidade Federal de São Paulo, Paulista Nursing School, Postgraduate Program in Nursing. São Paulo, Brazil.

How to cite this article:

Melo FBB, Marques CAV, Rosa AS, Figueiredo EN, Gutiérrez MGR. Actions of nurses in early detection of breast cancer. Rev Bras Enferm [Internet]. 2017;70(6):1119-28. DOI: http://dx.doi.org/10.1590/0034-7167-2016-0155

Submission: 05-10-2016 Approval: 11-13-2016

\begin{abstract}
Objective: Identify the actions for early detection of breast cancer performed by nurses from basic health units; compare the compliance of these actions with the recommendations from the Ministry of Health; analyze the availability of documents to check these recommendations and analyze the association of variables "training," "lato sensu training," and "years of activity" of these professionals with the actions performed. Method: A cross-sectional study conducted with 133 nurses from 38 basic health units in the Southeast region of the municipality of São Paulo, interviewed with a validated questionnaire. Result: Most nurses reported actions to detect this neoplasm. Guidance on the first mammogram age was significantly associated with training, years of activity and availability of Basic Attention Book $n^{\circ} 13$. Conclusion: This study observed a positive influence of training and years of activity on the actions for early detection of breast cancer and the need for adjustments in national guidelines.
\end{abstract}

Descriptors: Breast Neoplasms; Screening Programs; Primary Healthcare; Nursing Professional Role; Oncology Nursing.

\section{RESUMO}

Objetivo: Identificar as ações de detecção precoce do câncer de mama desenvolvidas por enfermeiros de Unidades Básicas de Saúde; comparar a conformidade dessas ações com as recomendações do Ministério da Saúde; verificar a disponibilidade de documentos para consulta dessas recomendações e analisar a associação das variáveis capacitação, formação lato sensu e tempo de atuação desses profissionais com as ações desenvolvidas. Método: Estudo transversal, realizado com 133 enfermeiros de 38 unidades básicas de saúde da região Sudeste do município de São Paulo, entrevistados utilizando questionário validado. Resultado: A maioria dos enfermeiros referiu realizar as ações para detecção desta neoplasia. A orientação da idade da primeira mamografia associou-se significativamente com capacitação, tempo de atuação e disponibilidade do Caderno de Atenção Básica $n^{\circ} 13$. Conclusão: Destaca-se a influência positiva da capacitação e tempo de atuação na realização das ações de detecção precoce do câncer de mama e a necessidade de ajustes para adequá-las às diretrizes nacionais.

Descritores: Neoplasias da Mama; Programas de Rastreamento; Atenção Primária à Saúde; Papel do Profissional de Enfermagem; Enfermagem Oncológica.

\section{RESUMEN}

Objetivo: Identificar las prácticas de enfermeros en la detección temprana del cáncer de mama en las unidades básicas de salud; compararlas con las recomendaciones del Ministerio de Salud brasileño; verificar la disponibilidad para consulta de dichas recomendaciones y evaluar la relación de las variables capacitación, formación lato sensu y tiempo de trabajo de estos profesionales con las prácticas empleadas por ellos. Método: Estudio transversal con 133 enfermeros de 38 unidades básicas de salud del municipio de São Paulo, región Sudeste, entrevistados mediante el cuestionario validado. Resultado: La mayoría de los enfermeros afirmaron realizar prácticas para detectar esta neoplasia. La orientación de la edad para realizar la primera mamografía se relacionó a la capacitación, el tiempo de trabajo y la disponibilidad del libro Atención Básica Básica nº 13. 
Conclusión: Se señala la influencia positiva de la capacitación y el tiempo de trabajo en realizar las prácticas para detectar precozmente el cáncer de mama y la necesidad de adaptarlas a las normas nacionales.

Descriptores: Neoplasias de la Mama; Tamizaje Masivo; Atención Primaria de Salud; Rol de Enfermeros; Enfermería Oncológica.

\section{CORRESPONDING AUTHOR_Fabiana Barbosa Barreto Melo E-mail: fabian_bs@yahoo.com.br}

\section{INTRODUCTION}

Breast cancer is the most frequent neoplasm among women worldwide, with estimated 1.67 million new cases in 2012, accounting for approximately $25 \%$ of all types of cancer $^{(1)}$. In Brazil, around 57,960 new cases are expected in 2016, with an estimated risk of 56.2 cases per 100,000 women ${ }^{(2)}$. Considering this reality, the early detection of this neoplasm has been included in public policies, with the creation of governmental programs to reduce the mortality rate, and physical, psychological and social impact of this disease in women's lives, and to support the expansion of services offered to this target population of oncology at all stages of the health-disease-care process $^{(3-4)}$.

To help achieve these objectives, initiatives for the primary healthcare system reorganization are highlighted to reinforce actions of health promotion and prevention of diseases and aggravations through the universal access to health and system decentralization ${ }^{(3,5)}$.

In the city of São Paulo, the primary healthcare system is structured in basic health units (BHUs) that conduct individual and collective actions, and offer two healthcare models: the traditional one and the Family Health Strategy $(\mathrm{FHS})^{(6)}$. In some BHUs, the two models are offered in the same structure, and they are called mixed BHUs.

At this level of attention, nurses find many possibilities to conduct their activities, as they have considerable autonomy in their practices, with effective participation in educational processes, social organization movements, and strategic leadership roles in management ${ }^{(7)}$.

Regarding the actions performed by nurses for early detection of breast cancer in BHUs, studies show the existence of gaps in such actions, both due to structural issues of the service (absence of a room to perform procedures) ${ }^{(8)}$ and lack of theoretical and technical knowledge of this subject (clinical and gynecological exams are incomplete in terms of integrality of women's healthcare $)^{(8-9)}$, and lack of awareness among professionals about the importance of a structured planning for these actions ${ }^{(8)}$. These studies also emphasize the need of nurse training ${ }^{(8-9)}$ through the development of effective strategies to fill these gaps ${ }^{(8)}$ and encourage them to prioritize the actions for early diagnosis of breast cancer ${ }^{(10)}$.

Thus, this study aimed to expand the knowledge about the nurse's role in breast cancer screening in primary healthcare, covering the actions in the nurse's scope of competence. The identification of early detection actions, according to the recommendations of the Ministry of Health $(\mathrm{MH})$, is believed to support the decision-making process of public managers from the administrative and educational sectors for the development of practices to an effective control of this disease.
Considering the above, this study aims to identify the actions for early detection of breast cancer conducted by $\mathrm{BHU}$ nurses; compare the compliance of these actions with the $\mathrm{MH}$ recommendations; analyze the availability of documents to check these recommendations and analyze the association of variables 'training,' 'lato sensu training,' and 'years of activity' of these professionals with the actions performed.

\section{METHOD}

\section{Ethical aspects}

The project was approved by the Research Ethics Committees (CEP) of Health Coordination for the Southeast region in the municipality of São Paulo and the Universidade Federal de São Paulo (UNIFESP), observing the legal and ethical requirements for human research.

\section{Study design, site and period}

A descriptive, cross-sectional study conducted at one BHU of the Southeast Health Coordination in the municipality of São Paulo, from January to March, 2014, and it is one of the investigations under the multicenter project "Actions for breast cancer control: identification of practices in primary healthcare."

Source of data, protocol, data collection and organization

A complex two-stage sampling plan was used to select the BHUs and the nurses to participate in this study. First, the health facilities were selected by means of a simple random sampling, using the models of 90 BHUs in force in 2011, leading to the selection of $38 \mathrm{BHUs}, 12$ of them were from FHS, 9 mixed BHUs, and 17 traditional BHUs. In the second stage, all nurses from the selected BHUs who met the inclusion criteria, that is, no restriction of age and sex and at least one year of activity in the $\mathrm{BHU}$, were invited to participate in this study. Those who did not work directly in the provision of care to patients and those in managing roles were excluded. Then, the sample consisted of 133 nurses, 62 from BHU FHS, 42 from mixed BHUs, and 29 from traditional BHUs.

A questionnaire was developed and validated by Marques ${ }^{(11)}$ to collect data of nurse identification and training, actions to control breast cancer (investigation of risk factors, clinical exam of breasts, mammogram, breast ultrasound, and breast self-exam), and general actions (information systems, educational meetings, and nursing consultation).

The nurses were interviewed by the study researcher, on a day and at a time previously scheduled, in a reserved area in the BHU to allow privacy. At the end of data collection, the information was sent to the database hosted on a website developed for the research group. 


\section{Data analysis}

Double data entry was used in $10 \%$ of the questionnaires and in $10 \%$ of the questions, with $100 \%$ agreement (Kappa coefficient: 1.00). A descriptive analysis (absolute and relative frequency) and an inferential analysis of data were performed through a bivariate analysis that used the chi-square test or Fischer's exact test. All tests performed took into consideration a bidirectional $\alpha$ of 0.05 and a $95 \%$ confidence interval $(\mathrm{Cl})$, and they were conducted with the support of IBM SPSS 20 (Statistical Package for the Social Sciences) and Excel 2010 (Microsoft Office).

\section{RESULTS}

The characterization data of all 133 nurses showed the years of activity of these professionals in the BHU ranged from one to over ten years, most of them $(86 / 64.7 \%)$ less than five years; $108(81.2 \%)$ reported a specialization course, in particular, Family Health Strategy (41.4\%) and Public Health $(23.3 \%)$. Regarding the training on recommendations from the 2004 Consensus Document for breast cancer control, 80 nurses $(60.2 \%)$ reported participation in such training, and when questioned about the date of the latest training, 40 of them $(50.0 \%)$ reported more than two years ago.

Chart 1 shows the actions conducted by nurses from a $\mathrm{BHU}$ for breast cancer control and the comparison with the $\mathrm{MH}$ recommendations from the 2004 Consensus Document ${ }^{(4)}$ and Basic Healthcare Book $n^{\circ} 13^{(5)}$.

Regarding the information system, 52 (39.1\%) nurses answered that this tool did not generate data that could help them plan actions for early detection of breast cancer; of which 31 (59.6\%) reported planning their management activities according to the demand. It should be noted that this question did not address the systems individually. Among the computerized systems implemented in the BHUs, the most relevant were the Integrated Management and Health Care System (SIGA, Sistema Integrado de Gestão e Assistência à Saúde), mentioned by 131 (98.5\%) nurses, followed by the Computerized System of Primary Healthcare (SIAB, Sistema Informatizado da Atenção Básica), with 110 mentions (62.7\%).

Chart 1 - Actions conducted by nurses from BHUs for breast cancer control, challenges they face when performing such actions, and comparison to recommendations from the Ministry of Health, São Paulo, Brazil, 2014

\begin{tabular}{|c|c|c|c|}
\hline & $\begin{array}{l}\text { Actions recommended by the } \\
\text { Ministry of Health for primary } \\
\text { healthcare professionals }\end{array}$ & $\begin{array}{l}\text { Actions conducted by nurses at basic } \\
\text { health units }\end{array}$ & Challenges \\
\hline 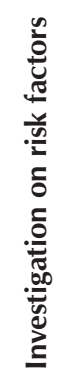 & $\begin{array}{l}\text { Investigation on risk factors for } \\
\text { breast cancer (age, genetic and } \\
\text { endocrine factors). } \\
\text { Individual clinical follow-up for } \\
\text { women at high risk of breast } \\
\text { cancer*. }\end{array}$ & $\begin{array}{l}\text { Of the sample, } 120(90.2 \%) \text { said they } \\
\text { performed this action, indicating the } \\
\text { following main factors to characterize } \\
\text { the population at high risk for breast } \\
\text { cancer: history of personal or family } \\
\text { breast cancer }(100.0 \%) \text {, smoking } \\
(75.0 \%) \text {, and history of personal or } \\
\text { family ovarian cancer }(62.5 \%) \text {. Of all } \\
120 \text { participants who investigated this } \\
\text { action, } 50.0 \% \text { reported that the return } \\
\text { visit for women at high risk should be } \\
\text { within three to six months. }\end{array}$ & $\begin{array}{l}\text { Of all } 13(9.8 \%) \text { participants who } \\
\text { said they did not investigate risk } \\
\text { factors, all informed lack of time as } \\
\text { the reason. }\end{array}$ \\
\hline 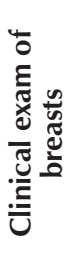 & $\begin{array}{l}\text { Annual CEB }{ }^{\oplus} \text {, in all women of } 40 \\
\text { years of age and older, and women } \\
\text { of } 35 \text { years of age and older if } \\
\text { belonging to groups of high risk for } \\
\text { developing breast cancer**. }\end{array}$ & $\begin{array}{l}\text { Of all participants, } 117(88.0 \%) \\
\text { reported CEB }{ }^{\Phi} \text { and } 113(96.6 \%) \text { of them } \\
\text { requested medical evaluation in case } \\
\text { of alteration in the exam, } 60(45.1 \%) \\
\text { reported "no age-related restriction" to } \\
\text { start the CEB }{ }^{\Phi} \text {. }\end{array}$ & $\begin{array}{l}\text { Of } 16 \text { participants who reported } \\
\text { no CEB }{ }^{\circledR} \text {, the lack of time was } \\
\text { mentioned by } 13 \text { of them. Among } \\
\text { the } 68 \text { participants who had } \\
\text { problems to perform this exam, } 48 \\
(70.6 \%) \text { also mentioned the lack of } \\
\text { time and } 20(29.4 \%) \text { absence of a } \\
\text { routine for this activity. }\end{array}$ \\
\hline 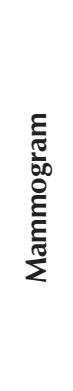 & $\begin{array}{l}\text { MMG }^{\circledR} \text { : women aged } 50 \text { to } 69 \text { years } \\
\text { every two years; } 40 \text { to } 49 \text { years, } \\
\text { diagnostic MMG }{ }^{\circledR} \text { in case of altered } \\
\text { CEB }^{\oplus} \text {. For women with high risk of } \\
\text { breast cancer, start at } 35 \text { years of age, } \\
\text { with annual exams**. } \\
\text { The nurse is responsible for checking } \\
\text { the results of the exams requested and } \\
\text { performed, and for referring them to } \\
\text { breast and cervical cancer diagnosis } \\
\text { and/or treatment*. }\end{array}$ & $\begin{array}{l}\text { Of the sample, } 97(72.9 \%) \text { reported that } \\
M^{\circ} G^{\otimes} \text { should be performed annually } \\
\text { and } 82(61.7 \%) \text { reported the age for the } \\
\text { first } M^{\circ} \mathrm{MG}^{\otimes} \text { is }>40 \text { years. } \\
\text { Of the sample, } 100(75.2 \%) \text { performed } \\
\text { an active search for women with } \\
\text { suspected report, and } 43(32.3 \%) \\
\text { referred them to reference services. } \\
\text { Active search for women who did } \\
\text { missed the exam was reported by } 37 \\
(27.8 \%) \text { professionals. }\end{array}$ & $\begin{array}{l}\text { Of } 133 \text { nurses, } 59(44.4 \%) \text { reported } \\
\text { challenges to perform } \mathrm{MMG}^{\otimes} \text {, } \\
\text { with scheduled exam reported by } \\
45(76.3 \%) \text { of them, and missing } \\
\text { patients by } 19(32.2 \%) .\end{array}$ \\
\hline
\end{tabular}




\begin{tabular}{|c|c|c|c|}
\hline & $\begin{array}{l}\text { Actions recommended by the } \\
\text { Ministry of Health for primary } \\
\text { healthcare professionals }\end{array}$ & $\begin{array}{l}\text { Actions conducted by nurses at basic } \\
\text { health units }\end{array}$ & Challenges \\
\hline 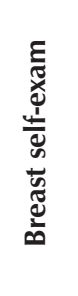 & $\begin{array}{l}\text { Recommend breast self-palpation } \\
\text { whenever the woman feels } \\
\text { comfortable, without recommending } \\
\text { any specific technique, valuing any } \\
\text { casual discovery of small breast } \\
\text { alterations. Recommend searching } \\
\text { for medical support in case of doubt } \\
\text { about the findings of breast self- } \\
\text { palpation**. }\end{array}$ & $\begin{array}{l}\text { Of all participants, } 123(92.5 \%) \\
\text { reported advising the patient on how } \\
\text { to examine her breasts; of these, } 60 \\
(48.8 \%) \text { advised that it should be during } \\
\text { the menstruation period. Monthly } \\
\text { exam was reported by } 95(77.2 \%) \\
\text { professionals. }\end{array}$ & $\begin{array}{l}\text { Seven of all } 10 \text { participants who } \\
\text { said they did not recommend } \text { BSE }^{\circledR} \\
\text { mentioned lack of time as the } \\
\text { reason. }\end{array}$ \\
\hline 苞 & $\begin{array}{l}\text { Develop individual or collective } \\
\text { educational activities that promote } \\
\text { community mobilization and } \\
\text { participation*. }\end{array}$ & $\begin{array}{l}\text { Of the sample, } 88(66.1 \%) \text { reported } \\
\text { educational actions about breast cancer } \\
\text { to patients. }\end{array}$ & \\
\hline 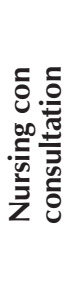 & $\begin{array}{l}\text { Conduct the nursing consultation and } \\
\text { CEB }{ }^{\circledR} \text { according to the patient's age } \\
\text { group and clinical profile. Request } \\
\text { exams according to the protocols } \\
\text { or technical standards established } \\
\text { by the local administrator. Examine } \\
\text { and evaluate patients with signs and } \\
\text { symptoms of cervical and breast } \\
\text { cancer**. }\end{array}$ & $\begin{array}{l}\text { Of the sample, } 127(95.5 \%) \text { reported } \\
\text { nursing consultation, ranging from } 10 \\
\text { to } 20 \text { visits per day, for } 86(67.7 \%) \text { of } \\
\text { them. }\end{array}$ & $\begin{array}{l}\text { Of the six nurses who reported not } \\
\text { performing nursing consultation, } \\
\text { five }(83.3 \%) \text { attributed it to work } \\
\text { overload. }\end{array}$ \\
\hline 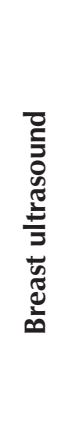 & $\begin{array}{l}\text { Breast US }{ }^{\oplus} \text { is the method of choice } \\
\text { for imaging exam of palpable lesion } \\
\text { in women of less than } 35 \text { years } \\
\text { of age. For women of } 35 \text { years of } \\
\text { age or older, mammogram is the } \\
\text { method of choice. Breast US }{ }^{\oplus} \text { is } \\
\text { a complement of } \mathrm{MMG}^{\circledR} \text { in the } \\
\text { following situations: - Nodule with } \\
\text { no expression; - Regular or slightly } \\
\text { lobulated nodule, which may be a } \\
\text { cyst; - Diffuse asymmetric density } \\
\text { that may be a solid lesion; cyst or } \\
\text { breast parenchyma**. }\end{array}$ & $\begin{array}{l}\text { Of total, } 92(69.2 \%) \text { reported that there } \\
\text { was no interval established for the } \\
\text { examination, since it depends on the } \\
\text { result of } \mathrm{CEB}^{\Phi} \text { and } \mathrm{MMG}^{\circledR} \text {. }\end{array}$ & $\begin{array}{l}\text { Of all } 75 \text { nurses who reported } \\
\text { challenges in the implementation of } \\
\text { the USG }{ }^{\oplus}, 69(92.0 \%) \text { mentioned } \\
\text { scheduling. } \\
\text { Of all } 38 \text { participants who reported } \\
\text { challenges in the evaluation of USG } \\
\text { by the physician, } 32(84.2 \%) \text { reported } \\
\text { the delay in the return visit scheduling. } \\
\text { Of all } 133 \text { nurses, } 65 \text { ( } 48.9 \%) \text { reported } \\
\text { that the waiting time between the } \\
\text { request for the exam and the return } \\
\text { with the result is }>6 \text { months. }\end{array}$ \\
\hline
\end{tabular}

Source: Caderno de Atenção Básica no 13* Documento de Consenso 2004**

Note: (1) Clinical exam of breasts; (2) Mammogram; (3) Breast self-exam; (4) Ultrasound.

The analysis of the association of variables nurse training and guidance for the age to start CEB, MMG, and BSE showed that the only action presenting an association with statistically significant difference was guidance for the age of first MMC $(p=0.045)$, answered by 72 nurses $(90.0 \%)$ who reported participation in training courses. Another variable that was significantly associated with training was conducts educational meetings, since this action was more frequent among those who received training $(p=<0.001)$ (Table 1$)$.

When analyzing the association between the fact that the nurses had specialization or not and provided guidance on the age for $C E B, M M G$ and BSE, no statistically significant difference was observed; however, the proportion of professionals with specialization and who provided guidance on the age for CEB (63/72.4\%) was higher than the proportion of nurses who provided guidance and had no specialization (29/63.0\%). A similar situation occurred with guidance on the age of the first MMG and BSE, showing that, for MMG, nurses with specialization were the ones who performed this action more frequently $(76 / 87.4 \%)$, when compared to those who provided guidance and had no specialization (36/78.3\%).

Tables 2 and 3 show the association of variables: years of activity in the BHU and availability of Primary Healthcare Book $n^{\circ} 13$ and guidance on the age of CEG, first MMG and $B S E$; they also show that nurses with fewer years of activity provided more guidance on the age of the first MMG $(p=0.010)$ and that the availability of Primary Healthcare Book $n^{\circ} 13$ had a statistically significant result for the guidance on the age of CEB $(p=0.042)$, the first MMG $(p=<0.001)$ and BSE $(p=0.049)$. 
Table 1 - Association between training on early detection of breast cancer and conducts educational meetings, guidance for the age of clinical exam of breasts, the first mammogram and breast selfexam, São Paulo, Brazil, 2014

\begin{tabular}{|c|c|c|c|c|c|c|}
\hline \multirow{3}{*}{$\begin{array}{c}\text { Training } \\
\text { on early } \\
\text { detection }\end{array}$} & \multicolumn{4}{|c|}{ Guidance on the age of CEB ${ }^{\circledR}$} & \multirow{3}{*}{$\begin{array}{c}\text { Total } \\
\mathbf{n}\end{array}$} & \multirow{3}{*}{$p$ value* } \\
\hline & \multicolumn{2}{|c|}{ No } & \multicolumn{2}{|c|}{ Yes } & & \\
\hline & $\mathbf{n}$ & $\%$ & $\mathbf{n}$ & $\%$ & & \\
\hline Yes & 20 & 25.0 & 60 & 75.0 & 80 & \\
\hline No & 20 & 40.0 & 30 & 60.0 & 50 & 0.081 \\
\hline \multirow[t]{4}{*}{ Total } & 40 & 30.8 & 90 & 69.2 & 130 & \\
\hline & \multicolumn{4}{|c|}{ Guidance on the age of first $\mathrm{MMG}^{\odot}$} & Total & \\
\hline & \multicolumn{2}{|c|}{ No } & \multicolumn{2}{|c|}{ Yes } & & $p$ value* \\
\hline & $\mathbf{n}$ & $\%$ & $\mathbf{n}$ & $\%$ & $\mathbf{n}$ & \\
\hline Yes & 8 & 10.0 & 72 & 90.0 & 80 & \\
\hline No & 12 & 24.0 & 38 & 76.0 & 50 & 0.045 \\
\hline \multirow[t]{4}{*}{ Total } & 20 & 15.4 & 110 & 84.6 & 130 & \\
\hline & \multicolumn{4}{|c|}{ Guidance on the age of BSE $^{\circledR}$} & Total & \\
\hline & \multicolumn{2}{|c|}{ No } & \multicolumn{2}{|c|}{ Yes } & & $p$ value* \\
\hline & $\mathbf{n}$ & $\%$ & $\mathbf{n}$ & $\%$ & $\mathbf{n}$ & \\
\hline Yes & 5 & 6.3 & 75 & 93.7 & 80 & \\
\hline No & 4 & 8.0 & 46 & 92.0 & 50 & 0.479 \\
\hline \multirow[t]{4}{*}{ Total } & 9 & 6.9 & 121 & 93.1 & 130 & \\
\hline & \multicolumn{4}{|c|}{ Conducts educational meetings $\left.{ }^{(}\right)$} & & \\
\hline & \multicolumn{2}{|c|}{ No } & \multicolumn{2}{|c|}{ Yes } & & $p$ value* \\
\hline & $\mathbf{n}$ & $\%$ & $\mathbf{n}$ & $\%$ & $\mathbf{n}$ & \\
\hline Yes & 17 & 21.3 & 63 & 78.7 & 80 & \\
\hline No & 24 & 49.0 & 25 & 51.0 & 49 & $<0.001$ \\
\hline Total & 41 & 31.8 & 88 & 68.2 & 129 & \\
\hline
\end{tabular}

Note: ${ }^{*}$ Fischer's exact test. $p$ value $=0.05$; (1) Clinical exam of breasts, Missing = 3; (2) Mammogram, Missing=3; (3) Breast self-exam, Missing=3; (5) Conducts educational meetings, Missing $=4$.

Table 2 - Association between years of activity in the basic health unit and the guidance provided by the nurse related to the age for the clinical exam of breasts, the first mammogram, and the breast selfexam, São Paulo, Brazil, 2014

\begin{tabular}{|c|c|c|c|c|c|c|}
\hline \multirow{3}{*}{$\begin{array}{l}\text { Years of } \\
\text { activity }\end{array}$} & \multicolumn{4}{|c|}{ Guidance on the age of CEB ${ }^{\oplus}$} & \multirow{3}{*}{$\begin{array}{c}\text { Total } \\
\mathbf{n}\end{array}$} & \multirow{3}{*}{$p$ value* } \\
\hline & \multicolumn{2}{|c|}{ No } & \multicolumn{2}{|c|}{ Yes } & & \\
\hline & $\mathbf{n}$ & $\%$ & $\mathbf{n}$ & $\%$ & & \\
\hline$<5$ years & 23 & 26.8 & 63 & 73.2 & 86 & \multirow{4}{*}{0.202} \\
\hline $5 \mathrm{I}-\mathrm{I} 10$ years & 7 & 30.4 & 16 & 69.6 & 23 & \\
\hline$>10$ years & 11 & 45.8 & 13 & 54.2 & 24 & \\
\hline \multirow[t]{4}{*}{ Total } & 41 & 30.8 & 92 & 69.2 & 133 & \\
\hline & \multicolumn{4}{|c|}{ Guidance on the age of first $\mathrm{MMG}^{(2)}$} & Total & \multirow{3}{*}{$p$ value* } \\
\hline & \multicolumn{2}{|c|}{ No } & \multicolumn{2}{|c|}{ Yes } & & \\
\hline & $\mathbf{n}$ & $\%$ & $\mathbf{n}$ & $\%$ & $\mathbf{n}$ & \\
\hline$<5$ years & 8 & 9.3 & 78 & 90.7 & 86 & \multirow{4}{*}{0.010} \\
\hline $5 \mathrm{I}-\mathrm{I} 10$ years & 5 & 21.7 & 18 & 78.3 & 23 & \\
\hline$>10$ years & 8 & 33.3 & 16 & 66.7 & 24 & \\
\hline Total & 21 & 15.8 & 112 & 84.2 & 133 & \\
\hline
\end{tabular}

To be continued
Table 2 (concluded)

\begin{tabular}{|c|c|c|c|c|c|c|}
\hline \multirow{3}{*}{$\begin{array}{l}\text { Years of } \\
\text { activity }\end{array}$} & \multicolumn{4}{|c|}{ Guidance on the age of $\mathrm{BSE}^{(3)}$} & \multirow{3}{*}{ Total } & \multirow{3}{*}{$p$ value $*$} \\
\hline & \multicolumn{2}{|c|}{ No } & \multicolumn{2}{|c|}{ Yes } & & \\
\hline & $\mathbf{n}$ & $\%$ & $\mathbf{n}$ & $\%$ & & \\
\hline$<5$ years & 3 & 3.5 & 83 & 96.5 & 86 & \\
\hline 5 I- 10 years & 4 & 17.4 & 19 & 82.6 & 23 & \\
\hline$>10$ years & 3 & 12.5 & 21 & 87.5 & 24 & 0.075 \\
\hline Total & 10 & 7.5 & 123 & 92.5 & 133 & \\
\hline
\end{tabular}

Note: *Fischer's exact test. $p$ value $=0.05$; (1) Clinical exam of breasts, (2) Mammogram, (3) Breast self-exam.

Table 3 - Association between the availability of the Primary Healthcare Book $n^{\circ} 13$ and guidance provided by the nurse regarding the age for clinical exam of breasts, first mammogram, and breast self-exam, São Paulo, Brazil, 2014

\begin{tabular}{|c|c|c|c|c|c|c|}
\hline \multirow{3}{*}{$\begin{array}{l}\text { Availability } \\
\text { of Primary } \\
\text { Healthcare } \\
\text { Book } n^{0} 13\end{array}$} & \multicolumn{4}{|c|}{ Guidance on the age of CEB ${ }^{\circledR}$} & \multirow{3}{*}{$\begin{array}{l}\text { Total } \\
\text { n }\end{array}$} & \multirow{3}{*}{$p$ value* } \\
\hline & \multicolumn{2}{|c|}{ No } & \multicolumn{2}{|c|}{ Yes } & & \\
\hline & $\mathbf{n}$ & $\%$ & $\mathbf{n}$ & $\%$ & & \\
\hline Yes & 21 & 24.1 & 66 & 75.9 & 87 & \multirow{4}{*}{0.042} \\
\hline No & 7 & 53.8 & 6 & 46.2 & 13 & \\
\hline Does not know & 13 & 39.4 & 20 & 60.6 & 33 & \\
\hline Total & 41 & 30.8 & 92 & 69.2 & 133 & \\
\hline \multicolumn{5}{|c|}{ Guidance on the age of first $\mathrm{MMG}^{\circledR}$} & Total & \multirow{3}{*}{$p$ value* } \\
\hline & \multicolumn{2}{|c|}{ No } & \multicolumn{2}{|c|}{ Yes } & & \\
\hline & $\mathbf{n}$ & $\%$ & $\mathbf{n}$ & $\%$ & $\mathbf{n}$ & \\
\hline Yes & 7 & 8.0 & 80 & 92.0 & 87 & \\
\hline No & 7 & 53.8 & 6 & 46.2 & 13 & \\
\hline Does not know & 7 & 21.2 & 26 & 78.8 & 33 & $<0.001$ \\
\hline \multirow[t]{4}{*}{ Total } & 21 & 15.8 & 112 & 84.2 & 133 & \\
\hline & \multicolumn{4}{|c|}{ Guidance on the age of $\mathrm{BSE}^{\circledR}$} & Total & \multirow{3}{*}{$p$ value* } \\
\hline & \multicolumn{2}{|c|}{ No } & \multicolumn{2}{|c|}{ Yes } & totai & \\
\hline & $\mathbf{n}$ & $\%$ & $\mathbf{n}$ & $\%$ & $\mathbf{n}$ & \\
\hline Yes & 4 & 4.6 & 83 & 95.4 & 87 & \multirow{4}{*}{0.049} \\
\hline No & 3 & 23.1 & 10 & 76.9 & 13 & \\
\hline Does not know & 3 & 9.1 & 30 & 90.9 & 33 & \\
\hline Total & 10 & 7.5 & 123 & 92.5 & 133 & \\
\hline
\end{tabular}

Note: *Fischer's exact test. $p$ value $=0.05$; (1) Clinical exam of breasts, (2) Mammogram, (3) Breast self-exam.

\section{DISCUSSION}

When analyzing the characteristics of nurses in this study, a large number of these professionals presented less than five years of activity in the BHU and, of that group, $52 \%$ had been working for less than two years. In agreement with this finding, a study in São Paulo described that $54.0 \%$ of primary healthcare professionals worked between 1 and 4 years, which may indicate staff turnover and, consequently, cause high workload for those who remain in the $\mathrm{BHU}$, and it could compromise the relationship with the patient and the quality of care ${ }^{(12)}$.

Having no experience can be a barrier for the nurse; however, the motivation to learn and consolidate as a professional can ensure greater commitment of new professionals. This controversial situation was observed in this study when analyzing the association between the years of activity in the BHU and 
performing actions for early detection of breast cancer, in which a statistically significant difference was observed between the nurses with fewer years of activity in relation to guidance on the age of the first MMG. In contrast, over five years of activity was not statistically significant for conducting these actions.

Another aspect to be considered is that more than half the nurses reported having participated in a training course on breast cancer screening, and $50 \%$ of them reported this training had been provided more than two years ago. A similar result was obtained in a study with primary healthcare unqualified nurses in Ribeirão Preto, in which 65.0\% reported having had it more than two years ${ }^{(13)}$. These findings highlight the need for additional institutional investment in permanent education of these professionals in their primary healthcare activities.

International studies also show this reality, with $92.0 \%$ of Saudi nurses reporting that they did not receive any training on breast cancer screening ${ }^{(14)}$, and among Nigerian nurses, only $4.3 \%$ received training on $\mathrm{BSE}$ and $5,2 \%$ on $\mathrm{CEB}^{(15)}$.

The impact of training on the actions for early detection of breast cancer, as analyzed in this study, showed a statistically significant difference only in guidance on the age of first MMG and educational meetings. Thus, it is not possible to state that the nurse's years of activity in the BHU participation in a training program are substantially influencing the disease control actions. A similar result was described in a study conducted with 62 nurses working in primary healthcare services in the Caribbean, in which no statistically significant association was observed between the level of knowledge of breast cancer and the professional experience and training ${ }^{(16)}$.

Despite these results, the importance of permanent education activities is reinforced as a strategy to qualify the professional practice. It is necessary to consider the various aspects that may influence the small impact of training activities on actions for early detection of breast cancer, such as nurse motivation and didactic-pedagogical strategies, among others.

When analyzing the association between having a specialization degree and the actions of early detection of breast cancer, no statistically significant difference was observed between these variables. In addition, considering the training of nurses, having a specialization degree did not contribute to more assertive practices in early detection of this neoplasm, although $41.4 \%$ were specialists in family health and $23.3 \%$ in public health. National data on primary healthcare nurse training showed that in São Paulo, 88.0\% are specialists in FHS, collective health or public health, and $2.0 \%$ had a master's degree in these areas ${ }^{(12)}$, findings that agree with found in this study. This result may suggest that the demand for specialization has increased due to labor market requirements that have established it as a prerequisite in the selection and hiring process, and due to the need for professional qualification to support their actions, which does not seem to be satisfactorily achieved.

In contrast, a study that evaluated the knowledge of 226 nurses in Turkey of some types of cancer, including breast cancer, showed that the scores obtained by those with a bachelor's or master's degree were higher than those without these degrees ${ }^{(17)}$.

When asked about the availability of support materials for reference at the $\mathrm{BHU}$, around two thirds of the nurses reported that the Primary Healthcare Book $n^{\circ} 13$ was available, which ensures access to information in the facility. Such availability had a significant impact on breast cancer control actions, considering that the higher proportion of nurses who reported provision of guidance on the age of CEB, BSE, and for the first MMG, was of professionals with available document for reference, confirming the assumption that having access to information supports the provision of healthcare.

A study on the prevention of cervical cancer in Rio de Janeiro confirms these findings, since its practice was also based on the theoretical-conceptual axis presented in the care protocol ${ }^{(18)}$.

Regarding the investigation of risk factors, most interviewees reported that they performed it in their practice. In this context, the most frequently mentioned risk factors were the personal and family history of this disease in both sexes and the history of personal or family cervical cancer. These data suggest that these professionals recognize the importance of identifying women who are susceptible to or at high risk for breast cancer, allowing nurses and other health professionals to offer proper care and guidance to this vulnerable group, as well as healthcare recommended by the Ministry of Health ${ }^{(5,19)}$.

On the other hand, $75.0 \%$ of the nurses point out smoking as one of the factors that characterize high risk for this disease, which suggests the need for a better clarification on the subject. A national study conducted with primary healthcare nurses also describes that these professionals highlight the family history and smoking ${ }^{(13)}$ as risk factors for the development of breast cancer, reinforcing the need for further clarification on this theme, considering the lack of consensus that would confirm the association of tobacco with the etiology of this neoplasm ${ }^{(20-21)}$.

Regarding the actions performed by primary healthcare nurses, most of them reported performing the CEB, which indicates compliance with the recommendations of the Ministry of Health in the period of data collection ${ }^{(4-5)}$. On the other hand, the fact that $45.1 \%$ of the interviewees mentioned no age restriction for this examination may indicate a proper practice for the integral healthcare for women ${ }^{(22)}$, but not when the focus is the opportunistic screening for breast cancer, since the Ministry of Health ${ }^{(4)}$ recommends that this exam should be conducted annually for all women of 40 years of age and older, and 35 years of age for women at high risk to develop this disease.

The annual frequency for CEB was mentioned by $54.1 \%$ of the nurses interviewed in this study, which is similar to the percentage found in a study with Caribbean nurses, in which $36 \%$ recommended this frequency ${ }^{(16)}$. However, it differs from a study conducted in Nigeria, in which the exam frequency was every two years ${ }^{(15)}$.

It should be noted that in the new National Guidelines for Early Detection of Breast Cancer, published by the Ministry of Health on October 5, 2015, the CEB is not recommended as a screening measure, since its benefits are uncertain and there is no evidence of its effectiveness in reducing the mortality rate ${ }^{(23)}$.

In this study, lack of time was the most frequent challenge mentioned by the nurses for not performing the CEB, a similar finding to a study conducted in one BHU in Ribeirão Preto ${ }^{(13)}$ and a study conducted in the East region of the municipality of São Paulo ${ }^{(24)}$. 
Regarding non-high risk women screening via MMG, the new 2015 guideline $^{(23)}$ still recommends this exam every two years for women between 50 and 69 years of age. In this study, most nurses mentioned that MMG should be performed annually by women aged 40 to 50 years, which does not agree with the guidelines of the Ministry of Health ${ }^{(23)}$; however, it agrees with data from a review study conducted in $2012^{(25)}$. A similar result was observed in a study conducted in Florianópolis, in which $41.4 \%$ of the women aged 40 to 49 years performed MMG annually ${ }^{(26)}$, suggesting that the recommendation considered by primary healthcare professionals is the one issued by the Brazilian Society of Mastology and Gynecology and Obstetrics.

This scenario of divergent recommendations for $\mathrm{MMG}^{(23,25)}$ may interfere with the actions performed by the nurses and it shows the need for a consensus among the different bodies that regulate this exam to standardize the actions to be conducted in this area and ensure a better control of the exam effectiveness.

It should be noted that in the municipality of São Paulo, during data collection for this study, it was prohibited to request MMG for screening. In this sense, the answers about age group and frequency of this exam reflect a practice so far guided by the medical professional conduct. Only in 2015 the Technical Manual of Women's Health in the BHUs presented a flowchart in line with the guidelines of the Ministry of Health allowing a nurse's request for screening $M M^{(22)}$. This new recommendation, according to a study in this field, represents the city's progress that appreciates the potential of nurses and it may contribute to improving the women's access to breast cancer screening actions.

Also regarding MMG, most professionals of this study $(68.4 \%)$ indicated that the waiting time between the request for this exam and the exam result ranged from 1 to 3 months, which is higher than the period reported in the 2015 Bulletin for early detection of breast cancer, published by the Instituto Nacional de Câncer José Alencar Gomes da Silva (INCA), which states that in Brazil, the period between the request for a screening mammogram exam from a health facility and its conduction at a radiological clinic was, on average and for $51 \%$ of all mammogram exams, of around ten days ${ }^{(27)}$.

Also, the exam report takes, on average and for $72 \%$ of screening mammograms, up to 10 days $^{(27)}$ to be released, which would result in a total of 20 days for the BHU to receive the result. However, for the population of this study, the possible delay may be related to a difficult exam scheduling, a situation reported by $76.3 \%$ of the nurses. These data are confirmed by studies conducted with nurses from Ribeirão Preto primary healthcare ${ }^{(13)}$ and users of the Unified Health System (SUS) ${ }^{(28)}$, in which exam scheduling is identified as one of the main obstacles to speeding up this exam process.

Another aspect that should be highlighted in this study is that most nurses reported non-referral of women with altered MMG exam to reference units. This result is due to the referral standard established in the municipality for breast cancer that centralizes this function on medical professionals. This problem extends outside the municipality of São Paulo - in Ribeirão Preto, $73.3 \%$ of the interviewees reported non-referral of women with suspected malignancy to reference units ${ }^{(13)}$. A risk of delayed diagnosis and beginning of the treatment may result from difficult access to a physician that performs this referral.

Regarding the women with MMG indicating suspected malignancy or those who did not perform the requested exam, active search was not mentioned in every cases, a situation also observed in a study conducted in Ribeirão Preto ${ }^{(13)}$. It should be noted that this gap may also lead to delayed diagnosis and beginning of the treatment. On the other hand, the interviewees and their respective teams lack efficient technologies to help to identify those patients who missed the exam. This situation also indicates failure of the primary healthcare unit to act as a coordinator of healthcare provision to these patients ${ }^{(3,5)}$.

In relation to $\mathrm{BSE}$, more than half the nurses answered that they provided guidance on when, how and how often to examine the breasts, in agreement with data from a study conducted in Ribeirão Preto, in which $70.0 \%$ of the interviewees reported such guidance ${ }^{(13)}$. This recommendation was considered a screening strategy for many years; however, studies have not found evidence supporting it as an effective method to reduce the mortality rate of this disease. Given the above, the Ministry of Health ${ }^{(23)}$ states that the exam is not recommended as a screening method for breast cancer, and it is up to the primary healthcare professional to implement awareness strategies to improve women's knowledge and attitudes regarding this disease and then allow its diagnosis in early or less advanced stages.

To support their actions for early detection of breast cancer, nurses can use the information systems deployed in the $\mathrm{BHU}$; however, more than one third of the interviewees reported that these data did not allow them to plan these actions and that such planning was based on the demand for healthcare, a situation that was also reported in the study conducted in Ribeirão Preto, in which $31.7 \%$ do not use this system for such purpose ${ }^{(13)}$. Given this context, the option or contingency of having to plan actions for early detection of breast cancer based on spontaneous demand can lead to failures in the correct identification of the target population and follow-up actions and cause overloaded health professionals, considering the demand for medical services is usually higher than the supply. During the studied period, the municipality of São Paulo had not yet joined the e-SUS Atenção Básica, a system that aims to restructure the primary healthcare information nationwide. Similarly, the Breast Cancer Information System (SISMAMA) and the Cancer Information System (SISCAN) were not populated by the BHUs, but by the Regional Health Coordination or Technical Health Supervision, a fact that may have influenced the perception of the nurses. Accessible and efficient information systems can support the planning of care and monitor the results of the actions conducted.

Regarding the educational meetings on breast cancer mentioned by $66.1 \%$ of the nurses, with a statistically significant difference between those who had received training and compared to those who had not, when nurses expand their knowledge, their critical assessment skills and awareness of the importance of their actions also increase ${ }^{(29)}$.

One of the moments that can be used by nurses for individual educational actions is the nursing consultation, which was mentioned by most participants of this study as 
the moment they used to perform the CEB and provide guidance on BSE. This study highlights the importance of nurses in primary healthcare, since nurses understand the daily life of people and has autonomy to develop care strategies for the individual, family and community ${ }^{(30)}$.

In view of the aforementioned, the actions recommended by the Ministry of Health for early detection of breast cancer are actually performed by primary healthcare nurses who participated in this study. However, some non-compliances, such as the recommended age for MMG, instructions on how to perform BSE, and planning of the actions according to the demand, show the need of institutional investment in training to these professionals and analysis of structural elements of the care provision process to optimize the existing human and material resources, aiming to improve the attention to the target population.

A situational diagnosis of the actions of nurses in the primary healthcare network is critical for the development of permanent education and health strategies for breast cancer. Nurses need to be able to identify early signs and symptoms of this neoplasm, since it is a type of cancer of good prognosis if diagnosed and treated in a timely manner. For this reason, the institutions should promote training opportunities with active and participative methodologies that make good use of distance education, allow changes in the work process through acquisition of knowledge and that value interdisciplinary and interprofessional actions.

\section{Study limitations}

A study limitation refers to data collection through self-report of nurses about the actions investigated and that are under their responsibility, considering that even in situations not perceived as threatening or punitive, some individuals may prioritize socially or professionally desirable reports. In addition, this technique is subject to limitations related to attention and memory of the interviewees, a situation that minimized, as the interviews were conducted in a reserved place and in a period the interviewees considered sufficient to answer the questionnaire. Then, despite these limitations, self-report is a valuable source of information, especially in studies that do not allow direct observation of the studied phenomenon. Another limitation refers to non-individual analysis of the influence of information systems on the planning of actions for breast cancer control.

\section{Contributions to nursing, public health or public policies}

The diagnosis of non-compliances in the group of actions conducted by nurses in the primary healthcare environment supports decision makers in planning strategies of professional training and practice to help nurses face the problems identified using data that correspond to the reality.

It is crucial to promote nurse awareness of the importance to learn the content of official documents about actions for early detection of breast cancer and absorb the information generated by computer systems for a more effective planning of the actions under each professional's competence.

\section{CONCLUSION}

The results of this study show that the actions for early detection of breast cancer to be conducted by primary healthcare nurses are actually being performed by them. However, when comparing the compliance of these actions with the guidelines recommended by the Ministry of Health to control this disease, adjustments are required, with investments in nurse training, to improve the quality of care. In addition, a positive influence of variables training, years of activity, and availability in the $\mathrm{BHU}$, and of the Primary Healthcare Book $n^{\circ} 13$ was observed on the provision of guidance to conduct these actions.

\section{FUNDING}

This study was supported by the CNPQ, Conselho Nacional de Desenvolvimento Científico e Tecnológico.

\section{REFERENCES}

1. Ferlay J, Soerjomataram I, Dikshit R, Eser S, Mathers C, Rebelo M, et al. Cancer incidence and mortality worldwide: sources, methods and major patterns in GLOBOCAN 2012. Int J Cancer[Internet]. 2015 [cited 2015 Nov 30];136(5):E359-86. Available from: https://dx.doi.org/10.1002/ijc.29210

2. Brasil. Ministério da Saúde. Instituto Nacional de Câncer José Alencar Gomes da Silva. Coordenação de Prevenção e Vigilância. Estimativa 2016: incidência de câncer no Brasil. Rio de Janeiro: INCA, 2015.

3. Marques CAV, Figueiredo EN, Gutiérrez MGR. Public health policies for breast cancer control in Brazil. Rev Enferm UERJ [Internet]. 2015 [cited 2016 Apr 18];23(2):272-8. Available from: http://www.e-publicacoes.uerj.br/index.php/enfermagemuerj/ article/view/13632

4. Brasil. Ministério da Saúde. Instituto Nacional de Câncer. Controle do câncer de mama. Documento de Consenso.[Internet]. Brasília; 2004 [cited 2016 Apr 18]. Available from: http://www.inca.gov.br/publicacoes/Consensointegra.pdf

5. Brasil. Ministério da Saúde. Secretaria de Atenção à Saúde. Departamento de Atenção Básica. Controle dos cânceres do colo do útero e da mama. (Cadernos de Atenção Básica n. 13) (Série A. Normas e Manuais Técnicos). [Internet]. Brasília; 2013 [cited 2016 Apr 18]. Available from: http://bvsms.saude.gov.br/bvs/publicacoes/controle canceres colo utero 2013.pdf

6. Marques CAV, Figueiredo EN, Gutiérrez MGR, Cassenote AJF. Breast cancer control in Primary Health Care: challenges in building a sampling plan. Rev APS [Internet]. 2014 [cited 2016 Apr 18];17(2):263-67. Available from: http://aps.ufjf.emnuvens.com.br/aps/ article/view/2186/811 
7. Costa SEM, Peres AM, Bernardino E, Sade PMC. Leadership styles that act of nurses in family health strategy. Cienc Cuid Saude[Internet]. 2015[cited 2016 Apr 18];14(1):962-9. Available from: http://www.periodicos.uem.br/ojs/index.php/CiencCuidSaude/article/ view/20756/14202

8. Cavalcante SAM, Silva FB, Marques CAV, Figueiredo EN, Gutiérrez MGR. Ações do Enfermeiro no rastreamento e diagnóstico do câncer de mama em mulheres: uma revisão integrativa de estudos brasileiros. Rev Bras Cancerologia[Internet]. 2013[cited 2015 Nov 30];59(3):459-66. Available from: http://www.inca.gov.br/rbc/n_59/v03/pdf/17-revisao_literatura-acoes-enfermeirorastreamento-diagnostico-cancer-mama-brasil.pdf

9. Bertocchi FM, Fernandes BM, Almeida MIG, Freitas SC, Paiva CCN, Paula EA. Professional conduct during breast and uterine/ cervical cancer screening consultations. Rev Rene[Internet]. 2014[cited 2015 Nov 30];15(6):973-9. Available from: www. revistarene.ufc.br/revista/index.php/revista/article/.../pdf_1

10. Oshiro ML, Bergmann A, Silva RG, Costa KC, Travaim IEB, Silva GB, Thuler LCS. Advanced breast cancer as a sentinel event for the evaluation of the breast cancer early detection program in the midwest of Brazil. Rev Bras Cancer. 2014;60(1):15-23.

11. Marques CAV, Figueiredo EN, Gutiérrez MGR. Validation of an instrument to identify actions for screening and detection of breast cancer. Acta Paul Enferm [Internet]. 2015 [cited 2016 Apr 18];28(2):183-9. Available from: http://www.scielo.br/pdf/ape/ v28n2/1982-0194-ape-28-02-0183.pdf

12. Galavote HS, Zandonade E, Garcia ACP, Freitas PSS, Seidl H, Contarato PC, et al. The nurse's work in primary health care. EsC Anna Nery Rev Enferm [Internet]. 2016 [cited 2016 Apr. 18];20(1):90-8. Available from: http://www.scielo.br/pdf/ean/v20n1/1414-8145ean-20-01-0090.pdf

13. Moraes DC, Almeida AM, Figueiredo EN, Loyola EAC, Panobianco MS. Opportunistic screening actions for breast cancer performed by nurses working in primary health care. Rev Esc Enferm USP [Internet]. 2016 [cited 2016 Apr 18];50(1):14-21. Available from: http://www.scielo.br/pdf/reeusp/v50n1/pt_0080-6234-reeusp-50-01-0014.pdf

14. Yousuf SA, Al Amoudi SM, Nicolas W, Banjar HE, Salem SM. Do Saudi nurses in primary health care centres have breast cancer knowledge to promote breast cancer awareness? Asian Pacific J Cancer Prev[Internet]. 2012[cited 2015 Nov 30];13(9):4459-64. Available from: https://www.ncbi.nlm.nih.gov/pubmed/23167361

15. Oluwatosin O. Primary health care nurse`s knowledge practice and client teaching of early detection measures of breast cancer in Ibadan. BMC Nursing[Internet]. 2012[cited 2015 Nov 30];29:11:22. Available from: https://www.ncbi.nlm.nih.gov/pmc/articles/ PMC3601001/pdf/1472-6955-11-22.pdf

16. Onuoha PC, Richards OS. Knowledge of breast cancer: a study of the primary health care (PHC) nurses of the caribbean island of St Vincent and the grenadines. Int J Curr Res[Internet]. 2014[cited 2015 Nov 30];6(12):11023-30. Available from: http://www. journalcra.com/sites/default/files/6833.pdf

17. Andsoy II, Gul A. Breast, cervix and colorectal cancer knowledge among nurses in Turkey. Asian Pac J Cancer Prev[Internet]. 2014[cited 2015 Nov 30];15(5):2267-72. Available from: https://www.ncbi.nlm.nih.gov/pubmed/24716968

18. Silva MM, Gitsos J, Santos NLP. Primary health care: cervical cancer prevention in nursing consultation. Rev Enferm UERJ[Internet]. 2013[cited 2015 Nov 30];21(esp.1):631-6. Available from: http://www.e-publicacoes.uerj.br/index.php/enfermagemuerj/article/ view/10039

19. Batiston AP, Tamaki EM, Souza LA, Santos MLM. Knowledge of and practices regarding risk factors for breast cancer in women aged between 40 and 69 years. Rev Bras Saúde Mater Infant[Internet]. 2011[cited 2015 Nov 30];11(2):163-71. Available from: http://www.scielo.br/pdf/rbsmi/v11n2/a07v11n2.pdf

20. Pimhanam C, Sangrajrang S, Ekpanyaskul C. Tobacco smoke exposure and breast cancer risk in Thai urban females. Asian Pac J Cancer Prev[Internet]. 2014[cited 2015 Nov 30];15(17):7407-11. Available from: https://www.ncbi.nlm.nih.gov/pubmed/25227850

21. Chen C, Huang YB, Liu XO, Gao Y, Dai HJ, Song FJ, et al. Active and passive smoking with breast cancer risk for Chinese females: a systematic review and meta-analysis. Chin J Cancer[Internet]. 2014[cited 2015 Nov 30];33(6):306-16. Available from: https:// www.ncbi.nlm.nih.gov/pmc/articles/pmid/24823992/

22. São Paulo (Cidade). Secretaria da Saúde. Manual técnico: saúde da mulher nas Unidades Básicas de Saúde / Coordenação da Atenção Básica/Estratégia Saúde da Família. 4ªed. Série Enfermagem[Internet]. São Paulo: SMS; 2015[cited 2016 Mar 28]. Available from: http:// www.prefeitura.sp.gov.br/cidade/secretarias/upload/saude/arquivos/legislacao/SaudedaMulher23092015.pdf

23. Brasil. Ministério da Saúde. Instituto Nacional de Câncer José Alencar Gomes da Silva. Diretrizes para a detecção precoce do câncer de mama no Brasil. Rio de Janeiro: INCA, 2015.

24. Garcia NK, Gonçalves R, Brigagão JIM. Primary health care actions aimed at women aged 45 to 60 years old. Rev Eletr Enf [Internet]. 2013 [cited 2016 Apr 18];15(3):713-21. Available from: https://www.fen.ufg.br/fen_revista/v15/n3/pdf/v15n3a13.pdf

25. Urban LABD, Schaefer MB, Duarte DL, Santos RP, Maranhão NMA, Kefalas AL, et al. Recommendations of Colégio Brasileiro de Radiologia e Diagnóstico por Imagem, Sociedade Brasileira de Mastologia, and Federação Brasileira das Associações de Ginecologia e Obstetrícia for imaging screening for breast cancer. Radiol Bras. 2012;45(6):334-9.

26. Schneider IJC, Giehl MWC, Boing AF, d'Orsi E. Mammogram screening for breast cancer and associated factors in the South of Brazil: a based-population survey. Cad Saúde Pública[Internet]. 2014 [cited 2016 Apr 18];30(9):1987-97. Available from: http:// www.scielo.br/pdf/csp/v30n9/0102-311X-csp-30-9-1987.pdf 
27. Brasil. Instituto Nacional de Câncer José Alencar Gomes da Silva. Boletim informativo detecção precoce. Monitoramento das ações de controle dos cânceres do colo do útero e de mama [Internet]. Rio de Janeiro: 2015 [cited 2016 Mar 22]. Available from: http://www1.inca.gov.br/inca/Arquivos/comunicacao/deteccao_precoce_12015.pdf

28. Gonçalves LLC, Travassos GL, Almeida AM, Guimarães AMDN, Gois CFL. Barriers in health care to breast cancer: perception of women. Rev Esc Enferm USP [Internet]. 2014 [cited 2016 Apr 18];48(3):394-400. Available from: http://www.scielo.br/pdf/ reeusp/v48n3/pt_0080-6234-reeusp-48-03-394.pdf

29. Graue M, Rasmussen B, Iversen AS, Dunning T. Learning transitions: a descriptive study of nurses' experiences during advanced level nursing education. BMC Nurs[Internet]. 2015[cited 2015 Nov 30];12:14:30. Available from: https://bmcnurs.biomedcentral. com/articles/10.1186/s12912-015-0080-z

30. Oliveira SKP, Queiroz APO, Matos DPM, Moura AF, Lima FET. Themes addressed in nursing consultation: integrative literature review. Rev Bras Enferm [Internet]. 2012 [cited 2016 Apr 18];65(1):155-61. Available from: http://www.scielo.br/pdf/reben/ v65n1/23.pdf 